Creative Commons User License: CC BY-NC-ND

Abstracted by: EBSCOhost, Electronic Journals Service (EJS), Google Scholar, Journal Seek, Scientific Commons,

Food and Agricultural Organization (FAO), CABI and Scopus

http://eoi.citefactor.org/10.11226/v24i3
Journal of Agricultural Extension

Vol. 24 (3) July, 2020

ISSN(e): 24086851; ISSN(Print); 1119944X

http://journal.aesonnigeria.org

http://www.ajol.info/index.php/jae

Email: editorinchief@aesonnigeria.org

\title{
Farm-Level Value Addition among Small-scale Mango Farmers in Machakos County, Kenya \\ https://dx.doi.org/10.4314/jae.v24i3.8
}

\author{
Musyoka, John Kennedy \\ Department of Agricultural Economics and Extension, \\ University of Embu, Kenya. \\ Email: kennedykinyutu@gmail.com \\ Phone: +254790344518

\section{Isaboke, Hezron Nyarindo} \\ Department of Agricultural Economics and Extension, \\ University of Embu, Kenya. \\ Email: hisaboke@gmail.com \\ Phone: +254705955732

\section{Ndirangu, Samuel Njiri} \\ Department of Agricultural Economics and Extension, \\ University of Embu, Kenya. \\ Email: ndirangu.samuel@embuni.ac.ke \\ Phone: +254723987104
}

\section{Abstract}

The study examined farm-level value addition among small-scale mango farmers in Machakos County, Kenya. A sample size of 352 small-scale mango farmers was proportionately selected from six wards of the study area. A structured interview schedule was used for data collection. Percentage and Heckman two-stage selection model were employed in data analysis. The result showed that only 33.52\% of the farmers practised mango value addition. Off-farm income, access to cold storage facilities, price of value-added products, group membership, extension contact, farmers' awareness, amount of credit and hired labour positively influenced mango farm-level value addition. Training, farmers' awareness and access to cold storage facilities positively influenced the proportion of mangoes value added at farm-level, while distance to market and livestock equivalence precipitated a negative effect on the proportion of mangoes value added. Relevant authorities in the County should provide adequate and up to date mango storage facilities and improve methods of extension delivery in order to increase the uptake of mango farm-level value addition among small-scale farmers.

Keywords: Farm-level value addition, extent of participation

\section{Introduction}

Agriculture plays a vital role in creating employment to a high proportion of people in most developing countries thus improving the livelihood of smallholder farmers (Rosairo and Potts, 2016). The sector also remains important in the poverty alleviation 
Creative Commons User License: CC BY-NC-ND

Abstracted by: EBSCOhost, Electronic Journals Service (EJS), Google Scholar, Journal Seek, Scientific Commons,

Food and Agricultural Organization (FAO), CABI and Scopus
Journal of Agricultural Extension

Vol. 24 (3) July, 2020

ISSN(e): 24086851; ISSN(Print); 1119944X

http://journal.aesonnigeria.org

http://www.ajol.info/index.php/jae

Email: editorinchief@aesonnigeria.org

target of Sustainable Development Goals (SDGs) at all levels by 2030 (Jha, Kickbusch, Taylor and Abbasi, 2016). Over $65 \%$ of the rural livelihoods who are economically active largely depend on the agricultural sector (Ntale, Anampiu, and Gathaiya, 2015). The agricultural sector is very crucial as it provides most of the food produced in Africa as well as the provision of over $70 \%$ of the workforce (Mkonda, 2017). Due to this, private sectors such as non-governmental organizations, farmers' self-help groups in collaboration with the regional and national governments have engaged to support growth and diversification of high-value agricultural produce. Such produces are highly perishable horticultural crops and fruits such as mango fruits.

Value addition is one of the diversification used in enhancing fast recuperation of investment and boosting farmer's income (Agwu, Anyanwa, and Kalu, 2015; Salvioni, Henke, and Vanni, 2020). Additionally, value addition enables small-scale farmers to reduce post-harvest losses and thereby offering them opportunities to maximize returns (Tobin, Glenna, and Devaux, 2016). Value addition is the process of converting a product from its original form to a more valuable form through creation of value and innovation (Oyewole and Eforuoku, 2019). In this study, mango value addition involves deliberate activities at the farm-level that transform mango fruits and makes it more valuable. Some of the value-added products that can be made from mango fruits at the farm-level include; mango juices, dessert, sliced and packed, dried mango among others. Furthermore, value addition also implies changing a raw product into something new through storage, packaging, processing, and drying or any other type of process that differentiates the product from its primary form. There is though low level of value addition practices among small-scale farmers (Ntale et al., 2015).

Value addition is achieved through innovation and coordination processes (Donkor, Onakuse, Bogue, and de los Rios Carmenado, 2018) . However, Farmers' interest to add value to their product through innovation and coordination is largely limited by the market environment, supportive services, processing technologies, infrastructure, institutional, economic, and socio-demographic factors (Gashaw, Habteyesus, and Nedjo, 2018). Kenya is among the leading producers of mango in Africa. The area under mango cultivation has been increasing over the years to 46,364 hectares in 2017 and 49,098 hectares in 2018 respectively (Horticultural Crop Directorate, 2018). Consequently, there is increased output at the farm-level that does not find markets hence results to high post-harvest losses. Measures such as value addition have been introduced as an intervention to increase the shelf life of mango, proper handling, and market access. However, in mango production, there has been low adoption of value addition technologies among small-scale farmers which predisposes the produce to spoilage due to high perishability (Kennedy, 2015). In Kenya, statistics show that only $6 \%$ of the small-scale farmers add value to their agricultural produce (Ntale et al., 2015).

Machakos County is the second leading producer of mangoes in Kenya after Makueni with 803,533 trees and an output of 67,320 MT, which is valued at Kenyan shillings (KES) 835,580,274 (Ministry of Agriculture Livestock and Fisheries, 2018). Mango is an important crop in this County for income generation among farmers. Moreover, $40-$ $60 \%$ of the population in the County engage in the mango value chain. This makes it 
Creative Commons User License: CC BY-NC-ND

Abstracted by: EBSCOhost, Electronic Journals Service (EJS), Google Scholar, Journal Seek, Scientific Commons,

Food and Agricultural Organization (FAO), CABI and Scopus
Journal of Agricultural Extension

Vol. 24 (3) July, 2020

ISSN(e): 24086851; ISSN(Print); 1119944X

http://journal.aesonnigeria.org

http://www.ajol.info/index.php/jae

Email: editorinchief@aesonnigeria.org

important for farmers to engage in value addition activities along the value chain to boost their income. The paper examined the determinants of farm-level value addition among small-scale mango producers.

\section{Methodology}

The study was carried out in Machakos County, Kenya. The County is located on latitude $0^{\circ} 45^{\prime} \mathrm{S}$ and longitude $36^{\circ} 45^{\prime} \mathrm{E}$. It is bounded in the West, North, East, South and South West and North West by Nairobi and Kiambu, Embu, Kitui, Makueni, Kajiado, Muranga and Kirinyaga respectively. The County covers an area of $6,208 \mathrm{~km}^{2}$ and has a population of 1,421,932 (Kenya Bureau of Statistics, 2019). In addition, the study area receives a bimodal rainfall pattern, with the long rains experienced in March to May, while short rains are received between October and November. The average annual rainfall ranges between 500 to $1300 \mathrm{~mm}$ per annum and temperatures range between $18^{\circ} \mathrm{C}-25.7^{\circ} \mathrm{C}$ (Government of Kenya, 2018). These conditions are therefore suitable for mango farming hence making the County be the second leading producer of mangoes in Kenya.

The target population was small-scale mango farmers who comprised of farmers practicing mango value addition (value adders) and those who do not (non-value adders). The study employed a two-stage stratified sampling procedure in which first, Machakos County was selected based on mango production. The second stage involved selecting six major mango producing wards which include; Mbiuni, Makutano/Mwala, Masii, Muthetheni, Wamunyu, and Kibauni. A location was then randomly selected from each of the six wards. Further, a Sub-location was selected from each location and finally, a village was randomly selected from each Sublocation. Probability proportionate to size technique was used to obtain the number of farmers to be interviewed in each village. Farmers were randomly sampled to make a sample size of 352 small-scale mango farmers.

The Heckman two-stage selection model was used to evaluate the determinants of farm-level value addition and the proportion of the mangoes value added among smallscale farmers. The first stage is a Probit model with a binary dependent variable ( $1=$ value adders, $0=$ non-value adders). For ease of interpretation of the significant variables, post-estimation of the selection equation results was done to determine the marginal coefficients (Table 4). This is because the coefficients of the first regression results have no direct interpretation since they consist of values that maximize the likelihood function. The second stage is an Ordinary Least Square (OLS) regression model and is used to evaluate the determinants of the proportion of mangoes value added. The model estimates the effect of these factors on the probability of value addition in the first stage and the proportion value added in the second stage. The Heckman two-stage selection model was specified as follows.

First Stage equation

$\begin{array}{lll}\operatorname{Pr}_{F L V} & =\quad & \beta_{0}+\beta_{1} X_{1}+\beta_{2} X_{2}+\cdots \beta_{n} X_{n}+\end{array}$ 
Creative Commons User License: CC BY-NC-ND

Abstracted by: EBSCOhost, Electronic Journals Service (EJS), Google Scholar, Journal Seek, Scientific Commons,

Food and Agricultural Organization (FAO), CABI and Scopus

http://eoi.citefactor.org/10.11226/v24i3
Journal of Agricultural Extension

Vol. 24 (3) July, 2020

ISSN(e): 24086851; ISSN(Print); 1119944X

http://journal.aesonnigeria.org

http://www.ajol.info/index.php/iae

Email: editorinchief@aesonnigeria.org

Where $P r_{F L V}$ is the probability of farmer carrying out value addition, $\beta_{0}$ is constant, $\beta_{1}$ to $\beta_{n}$ are the parameters to be estimated. $X_{1}$ to $X_{n}$ are the selected factors while $\varepsilon_{i}$ is the composite error term.

And;

$P r_{F L V}=1$ if $>0$,

$\operatorname{Pr}_{F L V}=0$ if $\leq$

0 ......

Second stage equation is given as;

$Y_{i}=\beta_{0}+\beta_{1} X_{1}+\beta_{2} X_{2}+\cdots \beta_{n} X_{n}+$

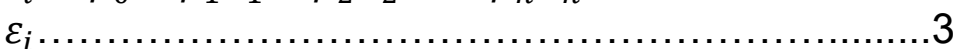

Where $Y_{i}$ is the proportion of the mango value-added in kilograms, $\beta_{0}$ is the constant, $\beta_{1}$ to $\beta_{n}$ are the parameters to be estimated, $X_{1}$ to $X_{n}$ are the selected factors and $\varepsilon_{i}$ is the composite error term.

\section{Results and Discussion`}

\section{Farmers Participation in Mango Value Addition Practices}

Table 1 indicates that $33.52 \%$ of the farmers practised value addition. Mango fruit can be converted to various products of value upon value addition, convenient to handle, and attractive to the consumers. Of those involved in value addition, $39.77 \%$ valueadded mango into juice, $28.41 \%$ desserts, $17.05 \%$ sliced and packed the mango while $14.77 \%$ carried out all mentioned value addition practices. This implied that the majority of the farmers in the study area value added mangoes into natural juices. Other more value-added products that can be made from mango fruits include sliced and dried mangoes, mango powder, mango wine among others. However, this was not among practices in this study as they require more advanced processing technologies which are of higher cost hence not accessible to small-scale farmers at the farm-level (Ndege, 2015).

\section{Table 1: Farmers participation in mango farm-level value addition}

\begin{tabular}{lr}
\hline Variable & Percentage Yes(\%) $\mathbf{n = 1 1 8}$ \\
\hline Farm-level mango value addition & 33.52 \\
Mango value-added products & 39.77 \\
Mango juice & 28.41 \\
Dessert & 17.05 \\
Sliced and packed mangoes & 14.77 \\
Mango juices, dessert, sliced and packed & \\
\hline
\end{tabular}


Creative Commons User License: CC BY-NC-ND

Abstracted by: EBSCOhost, Electronic Journals Service (EJS), Google Scholar, Journal Seek, Scientific Commons,

Food and Agricultural Organization (FAO), CABI and Scopus

http://eoi.citefactor.org/10.11226/v24i3
Journal of Agricultural Extension

Vol. 24 (3) July, 2020

ISSN(e): 24086851; ISSN(Print); 1119944X

http://journal.aesonnigeria.org

http://www.ajol.info/index.php/jae

Email: editorinchief@aesonnigeria.org

Categories of Farmers in Value Addition Practices and their Preferred Markets Table 2 shows various categories of farmers in value addition practices. The results indicate that $65.25 \%$ of the small-scale mango farmers practiced value addition in groups while $28.98 \%$ practiced value addition individually. Additionally, $5.77 \%$ practiced value addition both individually and in groups. Farmers who practice value addition individually do it for domestic consumption. In addition, farmers practice value addition majorly in groups since this provides for mobilizing capital for easy purchase of value addition equipment. Further farmers in groups easily exchange ideas about making various products thus enhancing value addition (Adeyonu, Ajala, Adigun, Ajiboye, and Gbotosho, 2016). The table also shows results on various preferred markets by the small-scale farmers for the sale of their products. The results show that $56.82 \%$ of the respondents sold their value-added products to the local markets within the county, $22.73 \%$ at farm gate, $11.36 \%$ to the brokers, and $9.09 \%$ in all those forms of markets. This shows that most of the small- scale farmers preferred the nearby local open-air markets. The plausible explanation of this is that markets are easy to access on specific market days when the majority of local buyers turn out in large numbers.

Table 2: Categories of farmers in value addition practices and their markets

Farmers characteristics in value addition

Percentage

$(n=118)$

\section{Categories of farmers in value addition}

Practicing value addition individually

Farmers groups

Both individually and in farmers group

Markets for value-added products

Local markets

56.82

Farm gate

22.73

Brokers

Sales to local markets, farm gate and to 9.09 brokers

\section{Farmers Awareness of Mango Farm-level Value Addition Strategies}

Figure 1 shows that about $51 \%$ of the farmers were aware of sorting and grading, followed by cold storage facilities (34.09\%) and packaging (14.77\%). Sorting and grading is an important practise in a quest to meet customers demand for quality and safety of the product. Further, packaging ensures safety handling and delivery of fresh and value added products. Cold storage facilities is one of the best strategies of value addition and post- harvest management practices in perishable produce like mango 
Creative Commons User License: CC BY-NC-ND

Abstracted by: EBSCOhost, Electronic Journals Service (EJS), Google Scholar, Journal Seek, Scientific Commons,

Food and Agricultural Organization (FAO), CABI and Scopus

http://eoi.citefactor.org/10.11226/v24i3
Journal of Agricultural Extension

Vol. 24 (3) July, 2020

ISSN(e): 24086851; ISSN(Print); 1119944X

http://journal.aesonnigeria.org

http://www.ajol.info/index.php/iae

Email: editorinchief@aesonnigeria.org

fruits (Alkan and Kumar, 2018). A study to assess the impact of value addition on farmers income found storage, packaging, sorting and grading to be the most used forms of value addition practices by the farmers groups (Mkandawire, Bett, and Gathungu, 2018).
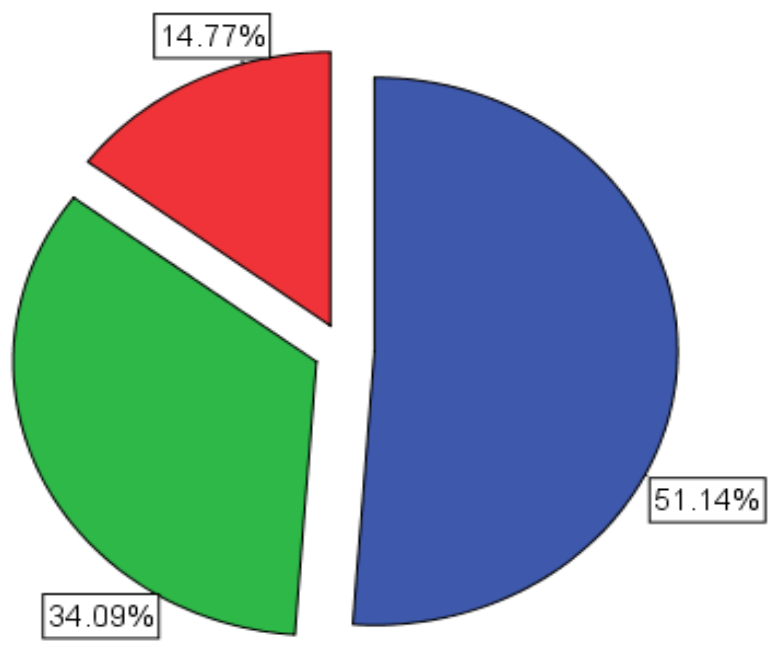

\author{
Value-addition \\ strategies \\ $\square$ Sorting and grading \\ $\square$ Storage \\ $\square$ Packaging
}

Figure 1: Farmers awareness of mango value addition strategies

\title{
Characteristics of Mango Value Adders and Non-Value Adders
}

The results in Table 3 indicate that $74.58 \%$ of the value adders are male. The results show that the proportion of males involved in value addition was higher compared to the females. The results further indicated that $65.25 \%$ of the value adders were members of an organized groups. The results show that the majority of farmers who practiced value addition were members of farmer groups (Table 3 ). There was a significant difference in mean farm size $\left(\chi^{2}=0.0002\right)$ between farmers that practiced value addition ( $x=1.45 \mathrm{ha})$ and those that did not $(\bar{x}=1.22 \mathrm{ha})$. This implies that farmers who practiced value addition had an average larger farm sizes than those who did not add value. There was a significant difference in the average number of mango trees owned $\left(\chi^{2}=0.0067\right)$ between farmers who practised value addition $(\bar{x}=22$ trees) and those did not ( $\bar{x}=19$ trees). This implies that value adders owned a higher number of mango trees compared to non-value adders. Moreover, there was a significant difference in the mean of the amount of credit used in value addition practices $\left(\chi^{2}=0.0011\right)$ between the value adders (USD 31.57) and non-value adders (USD 25.42). This indicate that farmers who extensively practice value addition allocate more credit to value addition practices. There was a significant difference in 
Creative Commons User License: CC BY-NC-ND

Abstracted by: EBSCOhost, Electronic Journals Service (EJS), Google Scholar, Journal Seek, Scientific Commons,

Food and Agricultural Organization (FAO), CABI and Scopus

http://eoi.citefactor.org/10.11226/v24i3
Journal of Agricultural Extension

Vol. 24 (3) July, 2020

ISSN(e): 24086851; ISSN(Print); 1119944X

http://journal.aesonnigeria.org

http://www.ajol.info/index.php/jae

Email: editorinchief@aesonnigeria.org

the mean number of visits by the extension officers $\left(\chi^{2}=0.0310\right)$ between the farmers that practised value addition ( $\bar{x}=3.14$ visits) and those did not $(\bar{x}=2.54$ visits). This indicates that value adders had largely eeived extension services than non-value adders hence prominently practiced mango value addition (Table 3 ).

Table 3: Comparison between mango value-adders and non-value adders'characteristics

\begin{tabular}{|c|c|c|c|c|}
\hline Variables & $\begin{array}{l}\text { Value- } \\
\text { adders (118) }\end{array}$ & $\begin{array}{l}\text { Non-value } \\
\text { adders ( 234) }\end{array}$ & $\begin{array}{l}\text { Pooled } \\
\text { Data (352) }\end{array}$ & \\
\hline \multicolumn{4}{|l|}{ Categorical variables } & $\begin{array}{l}\text { Chi-Square } \\
\text { test }\end{array}$ \\
\hline \multicolumn{5}{|l|}{$\begin{array}{l}\text { Gender }(1= \\
\text { Male, } 0=\text { Female) }\end{array}$} \\
\hline Male (\%) & 74.58 & 73.5 & 73.86 & $0.0467^{* *}$ \\
\hline Female (\%) & 25.42 & 26.5 & 26.14 & \\
\hline Group membership (yes\%) & 65.25 & 12.82 & 30.4 & $0.0000^{\star * \star}$ \\
\hline \multirow{2}{*}{\multicolumn{4}{|c|}{$\begin{array}{l}\text { Continuous variables } \\
\text { Household age (vrs.) }\end{array}$}} & t-test \\
\hline & 57.64 & 57.92 & 57.82 & 0.8299 \\
\hline Farming experience (yrs.) & 16.48 & 16.75 & 16.66 & 0.7905 \\
\hline $\begin{array}{l}\text { Mango farming income } \\
\text { (USD) }\end{array}$ & 237.87 & 222.50 & 232.72 & 0.5582 \\
\hline Off-year income (USD) & 1257.55 & 1076.85 & 1137.43 & 0.3090 \\
\hline Farm size (hectares) & 1.45 & 1.22 & 0.03 & $0.0002^{* * *}$ \\
\hline Prices per kg (USD) & 0.25 & 0.24 & 0.25 & 0.4638 \\
\hline Livestock equivalence & 41.73 & 40.58 & 40.97 & 0.6320 \\
\hline Training on value addition & 3.90 & 3.61 & 3.80 & 0.0748 \\
\hline Cost of packaging (USD) & 14.77 & 13.10 & 13.75 & 0.2098 \\
\hline Number of trees owned & 22 & 19 & 20 & $0.0067^{* *}$ \\
\hline Household size & 6.26 & 6.18 & 6.23 & 0.6760 \\
\hline Education attainment (yrs.) & 9.93 & 7.24 & 8.28 & 0.0730 \\
\hline Amount of credit (USD) & 31.57 & 25.42 & 27.48 & $0.0011^{* * *}$ \\
\hline Extension contact (visits) & 3.14 & 2.56 & 2.32 & $0.0310^{* *}$ \\
\hline
\end{tabular}

$\left({ }^{\star * *} P \leq 0.01,{ }^{* *} P \leq 0.05\right) ; 1$ USD $=$ KES 110

\section{Determinants of Farm-level Value Addition among Small-scale Mango Farmers}

The first stage analysis shows that the inverse mill ratio is positive and significant $(P \leq 0.01)$, (Table 4). This implies that there was a positive correlation of the error term in the two stages. The results in Table 4 indicate that off-farm income positively influenced the probability of farmers participating in value addition by $0.07 \%$. Access to off-farm income intensifies the monetary power of the farmers to participate more in the acquisition of value addition equipment and also caters for the labour that is incurred in value addition activities. Similarly, the amount of income from off-farm activities was found to positively influence farmers' decision to practice value addition 
Creative Commons User License: CC BY-NC-ND

Abstracted by: EBSCOhost, Electronic Journals Service (EJS), Google Scholar, Journal Seek, Scientific Commons,

Food and Agricultural Organization (FAO), CABI and Scopus
Journal of Agricultural Extension

Vol. 24 (3) July, 2020

ISSN(e): 24086851; ISSN(Print); 1119944X

http://journal.aesonnigeria.org

http://www.ajol.info/index.php/jae

Email: editorinchief@aesonnigeria.org

among smallholder farmers (Jakpa, 2016). Contrary, off-farm income was found to negatively influence the decision of smallholder farmers' participation in potato value addition activities in Uganda (Sebatta, Mugisha, Katungi, Kasharu, and Kyomugisha, 2015). Moreover, access to cold storage facilities positively influenced the likelihood of farmer's participation in mango value addition by $3.39 \%$.

The credible explanation for this is that the cold-storage facilities influence production as well as marketing because it reduces post-harvest losses during the peak season that might occur due to spoilage as a result of a long time that it takes to have produce to the market. This result concurs with the finding by Alkan and Kumar, (2018) that storage was one of the best strategies for mango value addition and post-harvest management practice among small-scale farmers. This finding contradicts results by Donkor et al. (2018) that lack of storage facilities reduces the active participation of farmers to value addition along the local value chain.

Furthermore, a one-unit increase in the price of value-added mango products significantly increases the probability of participation in value addition by $0.15 \%$. The prices of the value-added mango products are higher and more attractive to sellers compared to their raw form. These findings were consistent with Srivastava, (2017) that the price of value-added products among minor fruits in Eastern India positively influenced value addition. Additionally, Sebatta et al. (2015) found that the price of value-added potato products influences the probability of farmers' participation in farmlevel value addition activities among smallholder farmers in Uganda.

Membership of group influenced the probability of participation of farmers to value addition activities of the mango fruits by $1.93 \%$. A plausible explanation for this is that membership of groups, help farmers obtain and understand more on market information. In addition, farmers in groups, can easily receive training on value addition, exchange, and generate new notions and learn more about the benefits of value addition. This finding agrees with Donker et al., (2018) results that group membership had a positive influence on farmers' participation in value addition activities. Moreover, extension contacts on value addition influenced the probability of engaging in value addition activities by $3.02 \%$. Extension services in agriculture act as an intermediary between researchers, governments, and farmers. The services provided also include information regarding agricultural commodity production, marketing, innovations, agricultural commodity processing (value addition activities) as well as other opportunities available to farmers. Similarly, value addition was found to be influenced by extension services (Gashaw et al., 2018). So, the more the access to the extension service the more the farmer would be decisive on value addition.

Also, farmer's awareness on value addition influenced the likelihood of the farmer participation in farm-level value addition by $2.22 \%$. This is explained by the fact that small-scale farmers were aware of making various mango value-added products such as mango juice, dessert, sliced and packed. In addition, farmers were aware of key value addition practices such as sorting and grading, proper storage, and packaging. These results were in line with the result by Bonabana, Kirinya, Kasenge, Semalulu, 
Creative Commons User License: CC BY-NC-ND

Abstracted by: EBSCOhost, Electronic Journals Service (EJS), Google Scholar, Journal Seek, Scientific Commons,

Food and Agricultural Organization (FAO), CABI and Scopus

http://eoi.citefactor.org/10.11226/v24i3
Journal of Agricultural Extension

Vol. 24 (3) July, 2020

ISSN(e): 24086851; ISSN(Print); 1119944X

http://journal.aesonnigeria.org

http://www.ajol.info/index.php/jae

Email: editorinchief@aesonnigeria.org

and Mugonola, (2015) that awareness influenced farmers' participation in groundnut value addition technologies in Uganda. An increase in the amount of credit used in value addition by one unit increases the probability of farmers' participation in farmlevel value addition by $1.24 \%$. A plausible explanation for this is that access to credit is critical in financing investments and for purchasing mango value addition equipment as well as paying for various mango local processing operations.

Similarly, an increase in the amount of credit accessed positively increased the probability of farmers' participation in value addition activities among small-scale farmers (Sarma, Raha, Mia, and Jorgensen, 2016). With regard to labour, the availability of hired labour positively influenced the probability of the farmer practicing value addition by $0.65 \%$. Labour is a key input in production, value-addition, and marketing. The local processing of mango fruits requires physical labour input to carry out various activities such as peeling, sieving, and packaging. The results were similar to those of Tadesse, Shumeta, Tolemariam, (2017) that showed that accessibility of labour force positively influenced value addition among smallholder farmers.

Table 4: Determinants of mango farm-level value addition

\begin{tabular}{llll}
\hline Variables & Marginal Coef. & Std. Err. & Z \\
\hline Off-farm income (USD) & $0.0007 \mathrm{e}^{-4}$ & $0.0009 \mathrm{e}^{-4}$ & $2.9200^{\star \star *}$ \\
Household size & 0.0014 & 0.0095 & 0.5400 \\
Farming experience (yrs.) & 0.0001 & 0.0019 & 1.8600 \\
Cold storage facilities & 0.0339 & 0.0493 & $2.5800^{\star \star}$ \\
Training on value addition & 0.0071 & 0.0488 & 0.5500 \\
Cost of packaging (USD) & -0.0036 & 0.0443 & 0.3000 \\
Price of value added product & 0.0015 & 0.0022 & $2.5700^{\star \star}$ \\
Livestock equivalence & 0.0004 & 0.0007 & 1.9000 \\
Distance to market (Km) & 0.0056 & 0.0198 & 1.0600 \\
Distance to road (Km) & -0.0009 & 0.0301 & 0.1100 \\
Group membership & 0.0193 & 0.0293 & $2.4700^{\star *}$ \\
Extension contact (visits) & 0.0302 & 0.0275 & $4.1200^{\star * *}$ \\
Farmers awareness & 0.0222 & 0.0280 & $2.9700^{\star \star *}$ \\
Amount of credit (USD) & 0.0124 & 0.0136 & $3.4300^{\star \star *}$ \\
Hired labour (Man-days) & 0.0065 & 0.0091 & $2.6700^{\star * *}$ \\
Cost of storage (USD) & 0.0001 & 0.0004 & 1.2900 \\
Inverse mill Ratio & & 0.0329 & $4.5900^{\star \star *}$ \\
\hline
\end{tabular}

${ }^{* * *} \mathrm{P} \leq 0.01 ;{ }^{* *} \mathrm{P} \leq 0.05$

\section{Determinants of the Proportion of Mangoe Value Added among Small-scale Farmers}

Table 5 reveals that distance to the nearest market negatively affects the proportion of mangoes value-added. The results indicate that an increase in distance to the market by $1 \mathrm{Km}$ decreases the proportion of mangoes value added by 0.46 units. 
Creative Commons User License: CC BY-NC-ND

Abstracted by: EBSCOhost, Electronic Journals Service (EJS), Google Scholar, Journal Seek, Scientific Commons,

Food and Agricultural Organization (FAO), CABI and Scopus
Journal of Agricultural Extension

Vol. 24 (3) July, 2020

ISSN(e): 24086851; ISSN(Print); 1119944X

http://journal.aesonnigeria.org

http://www.ajol.info/index.php/jae

Email: editorinchief@aesonnigeria.org

Assuming that distance to the nearest market was a proxy for the access of marketing information where the market place is the source, farmers whose farms are located closer to the market, would have more interaction with information. Besides, this would create awareness about value addition, provide price information, and overall market conditions.

This finding agrees with the results by Khoza, Senyolo, Mmbengwa, Soundy, and Sinnett, (2019) that participation decisions and intensity of value addition was negatively related with distance from the market. Additionally, the number of training on value addition positively increased the proportion of mangoes value-added by 1.72 units. The credible explanation of this is that training on value addition brings a considerable impact on the participants in terms of the extent of perceived knowledge and acquisition of the skills on value addition activities. These findings concur with those of Adeyonu et al. (2016), that training on value addition significantly increases the farmer's decision to add value to sweet potatoes.

Likewise, farmer's awareness to value addition influenced the proportion of mangoes value added at the farm-level by 1.40 units. This indicates that farmer's awareness of value addition increases their willingness to make efforts in value-adding mangoes as well as understanding more on the upcoming value additions techniques. These findings agree with findings by Ndege, (2015) that increased farmer's awareness increases the access and use of knowledge on fruit processing technologies among smallholder farmers.

Moreover, the accessibility to cold storage facilities by the farmers positively influenced the proportion of the mangoes value added by 1.33 units. This indicates that farmers' access to storage facilities influences production and marketing since farmers can handle losses due to high yields. Cold storages increase the shelf-life of perishable products. These findings are similar to the results of Kyomugisha, Sebatta, and Mugisha, (2018) that access to the storage facilities positively and significantly influenced the on-farm value addition of potatoes among small-scale farmers.

Furthermore, Livestock equivalence negatively affected the proportion of the mango value added at the farm-level by a factor of 0.03 units. An increase in the total number of livestock owned by the farmers may bring about competition of the resources, and thus farmers might concentrate much on livestock rather than other farm-level value addition activities which yield better prices hence the negative effect. These findings are in line with those of (Davis and D'Odorico, 2015) that having other enterprises such as livestock keeping brings in competition of the resources with crops and thus reduces the amount of produce value-added in the value chain. 
Creative Commons User License: CC BY-NC-ND

Abstracted by: EBSCOhost, Electronic Journals Service (EJS), Google Scholar, Journal Seek, Scientific Commons,

Food and Agricultural Organization (FAO), CABI and Scopus

http://eoi.citefactor.org/10.11226/v24i3
Journal of Agricultural Extension

Vol. 24 (3) July, 2020

ISSN(e): 24086851; ISSN(Print); 1119944X

http://journal.aesonnigeria.org

http://www.ajol.info/index.php/iae

Email: editorinchief@aesonnigeria.org

Table 5: Determinants of the proportion of mangoes value added

\begin{tabular}{llcr}
\hline Variables & Coef. & Std. Err. & \multicolumn{1}{c}{$\mathbf{Z}$} \\
\hline Distance to market(Km) & $-0.4567^{\star}$ & 0.1620 & $-2.8200^{*}$ \\
Distance to motorable road (Km) & -0.1018 & 0.2278 & -0.4500 \\
Number of training on value addition & $1.7168^{*}$ & 0.3500 & $4.9100^{*}$ \\
Cost of packaging (USD) & 0.4087 & 0.3842 & 1.0600 \\
Farmers awareness on value addition & $1.4003^{*}$ & 0.2951 & $4.7500^{*}$ \\
Group membership & 0.1616 & 0.2944 & 0.5500 \\
Cold storage facilities & $1.3285^{*}$ & 0.3418 & $3.8900^{*}$ \\
Amount of credit used in value addition (USD) & 0.1734 & 0.2938 & 0.5900 \\
Livestock equivalence & $-0.0278^{\star}$ & 0.0051 & $-5.4300^{*}$ \\
Cost of storage (USD) & 0.0011 & 0.0041 & 0.2800 \\
\hline
\end{tabular}

${ }^{*} \mathrm{P} \leq 0.01$

\section{Conclusions and Recommendations}

The probability of farmers' participating in mango farm-level value addition is positively influenced by off-farm income, access to cold storage facilities, price of value-added products, group membership, extension contact, farmers' awareness, amount of credit and hired labour. Further, the proportion of mangoes value added is positively influenced by training, farmers' awareness and access to cold storage facilities, while distance to market and livestock equivalence precipitates negative effects on the proportion of mangoes value added.

Access to the storage facilities by small-scale mango farmers increases the availability of the product over a long time and this makes it fetch higher prices in the market especially when demand is high. In addition, farmers who are organized in groups can easily receive training on value addition, generate new ideas, and learn more about the benefits of value addition in a corporate manner. Furthermore, training of farmers on value addition increases farmers' knowledge and skills as well as their willingness to practice value addition.

The Ministry of Agriculture in collaboration with the county government and other private partners should increase the number of cold-storage facilities among smallscale mango farmers to promote the proportion of mangoes value added. The majority of mango farmers are members of various forms of groups, therefore value chain development agencies can target such groups for the provision of trainings on mango value addition practices. Furthermore, the relevant authorities should improve the methods of extension service delivery in order to increase the uptake of mango value addition through dissemination of information relating to value addition. It is also crucial to support mango farmers with adequate financial support through greater access to affordable credit. This will enable farmers to obtain improved or modern value addition equipments. 
Creative Commons User License: CC BY-NC-ND

Abstracted by: EBSCOhost, Electronic Journals Service (EJS), Google Scholar, Journal Seek, Scientific Commons,

Food and Agricultural Organization (FAO), CABI and Scopus

http://eoi.citefactor.org/10.11226/v24i3
Journal of Agricultural Extension

Vol. 24 (3) July, 2020

ISSN(e): 24086851; ISSN(Print); 1119944X

http://journal.aesonnigeria.org

http://www.ajol.info/index.php/jae

Email: editorinchief@aesonnigeria.org

\section{References}

Adeyonu, A. G., Ajala, A. O., Adigun, G. T., Ajiboye, B. O., \& Gbotosho, O. O. (2016). Determinants of sweet potato value addition among smallholder farming households in kwara state, Nigeria. Journal of Agro-Science, 15 (1), pp17-22.

Agwu, N. M., Anyanwu, C. I., \& Kalu, U. H. (2015). Factors influencing cassava value addition by rural agribusiness entrepreneurs in Abia state, Nigeria. Agriculture and Rural Development, 15 (3), pp19-24.

Alkan, N., \& Kumar, A. (2018). Post-harvest storage management of mango fruit. Achieving sustainable cultivation of mango. pp377-402.

Bonabana, W. J., Kirinya, J., Kasenge, V., Semalulu, O., \& Mugonola, B. (2015). Smallholder farmers access to improved groundnut production and value addition technologies in Eastern Uganda. Journal of Agricultural Extension and rural development, 7 (8), pp247256.

Davis, K. F., \& D'Odorico, P. (2015). Livestock intensification and the influence of dietary change: a calorie-based assessment of competition for crop production. Science of the Total Environment, 538, pp817-823.

Donkor, E., Onakuse, S., Bogue, J., \& de los Rios Carmenado, I. (2018). Promoting value addition among farmers in the cassava food value chain in Nigeria. British Food Journal, 120 (9), pp2047-2065.

Gashaw, B. A., Habteyesus, D. G., \& Nedjo, Z. S. (2018). Determinants of coffee value addition by smallholder farmers in Jimma Zone, Ethiopia. The International Journal of Business Management and Technology, 2 (8), pp2-13.

Government of Kenya. (2018). Kenya national bureau of statistics (KNBS). Statistical abstract, 2018, Nairobi.

Horticultural Crop Directorate. (2018). Validation report 2017-2018 Retrieved from horticulture.agricultureaouthority.go.ke, $2^{\text {nd }}$ July 2018.

Jakpa, M. M. (2016). Value chain and economic analysis of honey production in Nkwanta North and South Districts of the Volta Region (Doctoral dissertation).

Jha, A., Kickbusch, I., Taylor, P., \& Abbasi, K. (2016). Accelerating achievement of the sustainable development goals. British Medical Journal 352, pp1-2.

Kennedy, N. O. (2015). Adoption of value-addition technologies among mango fruit farmers in Machakos county. Kibabii University $1^{\text {st }}$ International Conference Proceedings; June 2224,2015 .

Kenya National Bureau of Statistics (2019). Economic survey; The Kenya population and housing census. Government printers, Nairobi, Kenya pp2319-7064.

Khoza, T. M., Senyolo, G. M., Mmbengwa, V. M., Soundy, P., \& Sinnett, D. (2019). Socioeconomic factors influencing smallholder farmers' decision to participate in the agroprocessing industry in Gauteng province, South Africa. Cogent Social Sciences, 5 (1).

Kyomugisha, H., Sebatta, C., \& Mugisha, J. (2018). Potato market access, marketing 
Creative Commons User License: CC BY-NC-ND

Abstracted by: EBSCOhost, Electronic Journals Service (EJS), Google Scholar, Journal Seek, Scientific Commons,

Food and Agricultural Organization (FAO), CABI and Scopus
Journal of Agricultural Extension

Vol. 24 (3) July, 2020

ISSN(e): 24086851; ISSN(Print); 1119944X

http://journal.aesonnigeria.org

http://www.ajol.info/index.php/jae

Email: editorinchief@aesonnigeria.org

efficiency and on-farm value addition in Uganda. Scientific African pp13-25.

Mkandawire, V. J., Bett, H. K., \& Gathungu, E. (2018). Determinants of participation in value addition activities among farmer groups in Ntchisi District, Malawi. 9(20), pp122-130.

Mkonda, M. Y., \& He, X. (2017). Yields of the major food crops: Implications to food security and policy in Tanzania's semi-arid agro-ecological zone. Sustainability, 9(8), pp1490.

Ministry of Agriculture Livestock and Fisheries (2018). Climate risk profile Machakos. Kenya county climatic risk profile series. The Kenya ministry of agriculture, livestock and fisheries, government printers, Nairobi, Kenya. pp1-24

Ndege, N. B. (2015). Access and use of knowledge on fruit processing technologies by smallholder farmers: A case study of Mwala, Machakos county (Masters thesis), University of Nairobi, Kenya. pp1-64

Ntale, J., Anampiu, R., \& Gathaiya, C. (2015). Agro-entrepreneurship readiness model: an empirical investigation in Kenya. International journal of development and sustainability, 4(7), pp825-839.

Oyewole, M. F., \& Eforuoku, F. (2019). Value addition on cassava wastes among processors in Oyo State, Nigeria. Journal of Agricultural Extension, 23(3), pp135-146.

Rosairo, H. S. R., \& Potts, D. J. (2016). A study on entrepreneurial attitudes of upcountry vegetable farmers in Sri Lanka. Journal of Agribusiness in Developing and Emerging Economies, 6 (1), pp39-58.

Salvioni, C., Henke, R., \& Vanni, F. (2020). "The impact of non-agricultural diversification on financial performance. Evidence from family farms in Italy. Sustainability, 12(2), pp486.

Sarma, P. K., Raha, S. K., Mia, M. I. A., \& Jørgensen, H. (2016). Factors influencing to adopt beef cattle agribusiness value addition in selected areas of Bangladesh. Journal of Agricultural Science 1(1), pp67-76.

Sebatta, C., Mugisha, J., Katungi, E., Kasharu, A. K., \& Kyomugisha, H. (2015). Adding value at the farm: The case of smallholder potato farmers in the highlands of Uganda. Asian Journal of Agricultural Extension, Economics \& Sociology, pp210-223.

Srivastava, A., Bishnoi, S. K., \& Sarkar, P. K. (2017). Value addition in minor fruits of Eastern India: An opportunity to generate rural employment. Fruits for livelihood: Production technology and management practices published by Agrobios (India), Jodhpur, India, pp395-417.

Tadesse, B., Shumeta, Z., \& Tolemariam, T. (2017). Determinants of milk value addition by farm households in Jimma Zone of South western Ethiopia. education, 3(2).

Tobin, D., Glenna, L. and Andre Devaux, A. (2016). Inclusion and exclusion in native potato value chains in the central highlands of Peru. Journal of Rural Studies, 46, pp71-80. 